\title{
Speaking the Unspoken: Rewriting Identity Loss and Memory of Slavery through Magical Realism in Toni Morrison's Beloved
}

\author{
Md Abu Shahid Abdullah ${ }^{1}$ \\ ${ }^{1}$ Department of English Literature, Otto-Friedrich University Bamberg, Germany \\ Correspondence: Md Abu Shahid Abdullah, Department of English Literature, Otto-Friedrich University \\ Bamberg, Germany. E-mail: jwl_abdullah@yahoo.com
}

\author{
Received: May 8, 2015 Accepted: June 2, 2015 Online Published: August 31, 2015 \\ doi:10.5539/ells.v5n3p25 URL: http://dx.doi.org/10.5539/ells.v5n3p25
}

\begin{abstract}
:
Toni Morrison seems to base her magical realism on the belief system of the African American cultural group, and her stories are strongly influenced by African American oral culture and mythology. In Beloved, she uses the magical realist technique to talk about the cruelty of slavery, to reinterpret the official history of white slave-owners and put an alternative history from the perspective of the slaves. It is not only the story of the protagonist Sethe, who killed her daughter in order to save her from the cruelty of slavery, but also the composite story of all slaves and their quest for freedom, and even of those who died in the 'Middle Passage' during their journey by slave ships. Morrison uses the magical realist device of a ghost named Beloved who is the embodiment of collective memories of black community and who, by reminding Sethe and other ex-black slaves of their past, allows them to tell their own story and to create their own version of history, and thus enables them to assert their identity which was lost through slavery. By dealing with historical issues critically and trying to cure historical wounds, magical realism in the novels mirrors history as well as strives to change it.
\end{abstract}

Keywords: Magical realism, alternative history, slavery, identity

\section{Introduction}

The critics of magical realism often express their understanding of the concept in terms of cultural conflict between dominant ruling classes, especially, male and white western elite, and those who have been devoid of power. Because of the dominant white supremacy in the culture of the United States and its significant immigrant society, the African Americans, like many other cross-cultural groups, consider that they are marginalized and un-represented in White American life which is also true for the African American women who face prejudice both as the members of a marginalized group and as women. Many women writers accepted the term 'magical realism' in the 1980s among whom the Nobel Laureate Toni Morrison is the most significant whose novels Song of Solomon (1977), Beloved (1987), and Jazz (1992) —all contain magical realist elements including the arrival of an 'abiku' child, the appearance of ghostly figures from the past, women with magical powers born without navels, and men that can fly. She seems to base her magical realism on the belief system of the African American cultural group rather than that of a particular location.

There is a strong influence of African American oral culture and mythology on Morrison's stories which are adapted from West African culture. Since one important aspect of magical realism is the use of myth, fable and folklore, she stresses on African American oral culture to recuperate black historical experiences. "In Beloved, black lore, the myths and rituals of black cultures are the most prominent element" (Razmi \& Jamali, 2012, p. 114). Morrison feels a strong connection with the predecessors who were the holders of cultural essence, and she employs magical realism in order to be able to use black folklore instead of authorized belief of the Western world. Her ghostly and magical character Beloved might have been created after a mixture of 'abiku', 'bakula', and 'orisha' of West African Yoruba mythology. Morrison's use of inherited myths to restore an identity lost by slavery provides her writing with a political dimension.

Beloved is conceived and written from the marginalized standpoint of African Americans who are devoid of any kind of social, cultural, and political authority. It is the story of Sethe, a female ex-slave, who murdered her baby girl in order to save her from clutches of slavery. Her grief is so intense that it is manifested into the body of a 
girl named Beloved, the same age of Sethe's murdered daughter if she had been alive. Although the novel is the story of Sethe, it is also the story of all the slaves of the Sweet Home plantation of Kentucky: Baby Suggs, Paul D, Paul F, Paul A, Helle Suggs, and Sixo. It is the composite story of all slaves and their quest for freedom, and even of those who died in the 'Middle Passage' during their journey by slave ships. According to Samuels \& Hudson-Weems (1990), Beloved depicts the cruelty, violence, and degradation-whether the physical floggings or the psychological fragmentation of the black family-that often victimized slaves, irrespective of age or gender (p. 96). The existence of two opposing forces of magic and real in Beloved probably mirrors the tensions between the oppressed and oppressor discourses. Morrison "uses the magical realist device of a revenant ghost child in full bodily form to bring back the memories of the heavily traumatized escaped slave Sethe (Bowers, 2004, pp. 80-81). By dealing with historical issues critically and trying to cure historical wounds, magical realism in the novel mirrors history as well as strives to change it. Sethe's daughter Denver, along with the help of Beloved, draws out her gruesome past so that they can go through a process of healing. Morrison's use of magical realism allows them to create history themselves by telling stories to each other made up from the bits and pieces of the past they have been able to accumulate. The aim of the article is to show how Morrison has used the magical realist technique to talk about the history of slavery of African Americans from their own perspective, to reinterpret the official history of white slave owners and put an alternative version from the perspectives of slaves, to heal traumatic memory, and to reestablish the identity lost through slavery.

\section{Discredited Magic of Disgraced People}

The term 'magical realism', which was "first coined by German art critic Franz Roh in 1925" (Bowers, 2004, p. 8), has been used by writers from all over the world, either as a literary technique, device or a genre of fiction, in their own ways and to serve different purposes. The term is associated with putting magical or supernatural events into realistic narrative to have a deeper understanding of reality without suspecting the improbability of these events. These magical elements are illustrated like normal happenings that are presented in a clear-cut manner which allows the real and the fantastic to be accepted in the same stream of thought. Through magical events writers can find new viewpoints and can open new windows through which they can see the world differently; they can find truth, can place and establish an alternative history in oppose to the official version of history. These magical events take place in a real world and through which the stories remain intimate, not unbelievable. Although there is a misconceived assumption that magical realism is specifically Latin American yet, the recognition of Latin American magical realism has pushed the quick adoption of this form of writing all over the world. Magical realism has become a common narrative style for novels written from the point-of-view of the politically, socially or culturally marginalized and oppressed, such as the native people living under colonial system, women writing from a feminist viewpoint, black people under white dominance or those who live with different cultural and religious beliefs and customs in another country where they are the minority, and the main intention behind using this kind of writing is to challenge the statement of a colonialist or official attitude, to disturb the established version of truth and history, and to rewrite the history from the marginalized perspective.

In an interview, Toni Morrison makes the distinction between African American folk culture and Latin American magical realism where she says that the main difference between these two expressions is their different origin, and she identifies herself with the black people who had to invent their magic in the midst of a new American reality; she states that their magic was discredited because it was held by discredited people (Taylor-Guthrie, 1994, p. 243). In her novel, she re-imagines the multidimensionality of slavery, and projects black people's magical superiority of their disgraced condition through a lot of apparently extraordinary day to day survival tactics. "As a result, while incorporating supernatural occurrences that appear real and ordinary, Morrison at the same time subverts this characteristic of magical realism by rendering the ordinary magical, the real miraculous" (Lobodziec, 2012, p. 111). This happens in Beloved when a white girl Amy sees Sethe's puffy feet and compares them to those of a dead man whose body she once saw while she was fishing. "Then she did the magic: lifted Sethe's feet and legs and messaged them until she cried salt tears" (Morrison, 1988, p. 35). Paul D's presence causes other people to open up and confess: "Emotion sped to the surface in his company. Things became what they were: drabness looked drab; heat was hot. Windows suddenly had view. And wouldn't you know he'd be a singing man" (p. 39). Baby Suggs possesses the magical power of multiplying things, especially, food items which reminds us of what Jesus Christ did with His disciples: “ Baby Suggs' three (may be four) pies grew to ten (may be twelve). Sethe's two hens became five turkeys. The one block of ice brought all the way from Cincinnati- over which they poured mashed watermelon mixed with sugar and mint to make a punchbecame a wagonload of ice cakes for a washtub full of strawberry shrug." (p. 137) 
One important feature of the novel's magical realism is the passages which hint that certain characters are bestowed with the magical knowledge of future events. When Baby Suggs wakes up to a "scent of disapproval" (Morrison, 1988, p. 137), which, she believes, has emerged from the black community that forsook her, she, at once, experiences a premonition directing towards ultimate tragedy. "Suddenly, behind the disapproving odor, way way back behind it, she smelled another thing. Dark and coming. Something she couldn't get at because the other odor hid it" (p. 138). This premonition comes just before the Schoolteacher, along with one nephew, one slave-catcher, and a sheriff, arrives at 124 in order to arrest Sethe, who is a runaway slave and who resists her arrest by attempting to kill her children. Again, the presence of Beloved, the ghost of the baby child who possesses magical powers, is also a magical realist event in the novel. She seems to know what Paul D is thinking when he promises to himself to make some investigation about her identity in the town; in the clearing Sethe is choked by a spirit and Denver realizes that it is done by Beloved from afar (p. 96); and Beloved's ability to disappear and reappear as she does one day right before Denver's eyes in the cold house (p. 122). Throughout the Morrison's novel, Beloved floats in the space where the ordinary becomes extraordinary, where something familiar seems strange and unfamiliar.

The undermining power of magical realism originates from the "juxtaposition of objective and subjective realities in ways that call the objective into question, allowing authors to challenge official readings of social, political and historical events" (cited in Razmi \& Jamali, 2012, p. 113). The source of this subversive and transgressive aspect of magical realism in Beloved lies in the fact that once the reader finds that the category of the real is not certain then all assumption of truth becomes vague, and once the category of real is suspected within the fiction, the world outside the fiction is made less certain as well. In Beloved, we do not find any difference between the spiritual world and material world, between the living and the dead, between past, present and future. In this novel, Morrison, in her attempt to provide the history of the black slaves from their own perspectives to that supported by the dominant power, uses oral story-telling as a source of alternative perspectives on history since the oral tale was often the only way in which alternative version of events survived. The political objective of the text is that the disposed, the silenced, and the marginalized of our own dominating systems can find voice. The adaptation of oral story-telling techniques in a magical realist narrative is often complementary and mutually supportive. "In a text where categories between the real and the magical have already been broken down, allowing for more than one version of truth to be proposed, the use of such story-telling techniques, which assume that there are multiple versions of a story, emphasizes the possibility of expressing multiple perspectives in the text" (Bowers, 2004, p. 90).

The supernatural presented in Beloved is a subalternized reality; it expresses social and cultural oppression, and is related to the gruesome experiences of the African Americans in the nineteenth century US society. "White people believed that whatever the manners, under every dark skin was a jungle. Swift unnavigable waters, swinging screaming baboons, sleeping snakes, red gums ready for white blood" (Morrison, 1988, p. 198). The novel forms a web of unions between the subconscious, the socially and culturally repressed women within a patriarchal society, and the ghost of what Baby Suggs calls "some dead Negros's grief" (p. 5). Morrison states that the history of slavery of African-Americans has remained unexpressed because of the disregard of dominant and previously slave-owning American culture. The magical realism expressed in Beloved is an ethnicized and marginalized world that indicates the huge rift between white and black worlds. The white people are unable to see, hear, or feel ghosts not because they cannot exist scientifically but because they (white people) are the means of oppression and domination. Morrison's claim that magical realism provides another way of knowing things, allows the expression of the unexpressed stories of the black slaves that go against the documented history from a European-American point-of-view.

The African American response to Euro-American modernity encompassed black people's reinterpretation and affirmation of their humanity which white supremacy questioned or even denied (Lobodziec, 2012, p. 112). Although Morrison's employment of magical realism might differ from other magical realists, her concern for African Americans still seems to be quite at tune with important issues taken up by Latin American magical realists like Gabriel García Márquez, for instance, the ideological justification of the dehumanization of black slaves by western science and philosophy. Amaryll Chanady (1995) writes,

Magical realism subverts the canons of ethnographic representation. The dichotomization between the non-reflexive primary society and the Western ethnographer's discourse of knowledge is dissolved by a novelistic discourse in which there is an attempt [...] to represent an indigenous worldview by means of a non-European focalizer. (p. 140)

In the novel, the character of school-teacher is the epitome of western ethnography and history. While writing a book about the black slave, he measures Sethe's face with a string, and asks his students to describe her by 
putting "her human characteristics on the left; her animal ones on the right" (Morrison, 1988, p. 193). In another instance, a newspaper clipping reports Sethe's infanticide where it aims to project black people as immoral, threatening, wicked and evil but what it avoids is the victimization and the inhuman treatment of the enslaved. Morrison focuses on the intensity of the characters' emotions and thus opposes the disgracing official history of black people; she wishes to say that black people are not evil, rather are the victim of white oppression. One noticeable symbol of black people's dehumanization and victimization is a humiliating and destructive iron horse bit placed in the mouth of the slaves irrespective of age and gender. Again, the chained black slaves are forced to live on the level of animals or even the worse. Morrison gives us an access to Sethe's past by introducing the magical character Beloved, and thus enables us to understand the brutality of slavery which has so long been silenced and suppressed in documented history.

\section{Healing Memory and the Past of Slavery}

The magical realist work of Morrison can successfully challenge the past and determine the history of America with the reality of the current time. She can recover history and undermine it; she can also show the common and mundane as reality and then introduce the world of the spirit as actuality. Wendy B. Faris (2004) says that one of magical realism's paradoxical projects is how to be grounded in history but not crushed by it and, alternatively, how to rise above it enough to reimagine it without shortchanging its intractability (p. 59). By this reimagination, magical realist writers like Morrison can confront existing discussion of power. The focus on the inner reality of the characters' life through the use of magical realism seeks to portray such history which is sensed as opposed to the recognized or accepted history. Based on the intensity of the characters' emotions, Morrison defies the bias of documented history recorded by the white slave owners which has, on the one hand, fabricated the slave stories and, on the other hand, silenced many personal histories of the enslaved black people and disgraced them. Her magical realism stresses the distinctiveness of the experience of the black slaves, and counters their discredit with a positive vision, and according to her understanding, "the magical dimension of that experience is an effective survival strategy which enables black people to physically, psychologically, and spiritually endure" (Lobodziec, 2012, p. 117).

The novel Beloved serves Morrison's important goal of portraying the life of slaves in such a way that has not been done before; it is an endeavor not to portray what history has recorded in the slave-narratives but what it has omitted. Although these slave-narratives vividly portray the cruelty, heinousness and inhumanity, they do not want to offend the white audience by being angry and outrageous which makes compromise necessary, and pulls a veil over the happenings. "What was silenced or forgotten in slave-narratives of the $19^{\text {th }}$ century has often remained unremembered and unspoken into the $20^{\text {th }}$ century" (Peterson, 2008, p. 23). Morrison wants to remember the unremembered and speak the unspoken and, through the narrator, desires to reveal the wrong and to correct the full story, but her endeavor requires that she depends upon the memories of others and that she draws upon the memories within. The reader should not merely know about the horror of slavery but feel what it was like. Apart from exploring the trauma that slavery wreaked on those who survived into the post-Civil War period, Morrison ambitiously attempts an imaginative testimony, through the figure of Beloved, of those who did not survive: those sixty million and more to whom the novel is dedicated. The novel challenges its readers to recognize the unbearable poignancy of the claims of the past- the loss suffered not just by those who survived, but also by those who did not. In order to reveal the silenced, marginalized and untold histories of the black slaves, Morrison uses the blend of the magical and the real where she introduces her ghost like character Beloved and exposes the shocking histories of black slaves which, by going completely against the authoritative history, starts a new beginning. According to Ashraf Rushdie (1999),

Perhaps the greatest achievement of Morrison's novel is that she gives the murdered victim of history 'voice'; she resurrects the unjustly killed and allows the daughter to have renewed historical life by criticizing the sort of history that has hitherto excluded her and her rebellious spirit .... In giving that 'ghost' a renewed voice and life, Morrison not only criticizes the institution responsible for Beloved's death but also shows the healing knowledge that accrues to those attentive to the ghost's presence. What Morrison does in Beloved is to remember in order to revive, to survive, to rename, and to repossess. (p. 61)

Morrison knows that the history of the slaves, from their own standpoint, has remained unexpressed due to the dominant American and former slave-owning culture. The process of writing Beloved was of difficulty and hindrance not only due to her own averseness to write about slavery, but due to the national amnesia on the subject. In an interview with Time magazine, she says, "I thought this has got to be the least read of all the books I've written because it is about something that the characters don't want to remember, I don't want to remember, black people don't want to remember, white people don't want to remember. I mean, it's a national amnesia" 
(cited in Matus, 1998, p. 103). People want to forget the issue of slavery, and the problem emerges from the inability to the complete recognition of slavery which can be found in the fragmented memories of the daily life that haunts individuals and groups. Morrison says, "There is a necessity for remembering the horror, but $[\ldots .$.$] in$ a manner in which it can be digested, in a manner in which the memory is not destructive. The act of writing the book, in a way, is a way of confronting it and making it possible to remember" (cited in Matus, 1998, p. 32). In Beloved, she seeks to find and expose the truth about "the interior life of people who didn't write it which does not mean that they didn't have it"; to "fill in the blanks that the slave narratives left"; to "part the veil that was frequently drawn"; and to "implement the stories that she had heard" (cited in Samuels \& Hudson-Weems, 1990, p. 97). For Morrison, writing about Sethe and the black community was more than a psychological exercise, acted upon by the imagination, to turn thoughts into art. It was, through inclusion of her memories, an act of writing a part of herself into the narrative and the result of which is a view on slavery unheard before, she claims that the characters are her entrance into her own interior life.

In many ways, Beloved depends on the tradition of ghost story: the haunted house, noises, smells, lights, displaced objects, an ominous atmosphere, and the perception and fear of a dog to the presence of ghost. The supernatural character Beloved possesses many typical characteristics of ghosts which include "new skin marked only by the scars of her violent death, supernatural strength, the ability to change shape and form at will and to cast spell on others" (Matus, 1998, p. 114). But the presence of ghost in Sethe's house at 124 is shown as if it were a normal and mundane event. When Paul D walks into a pool of red and undulating light and feels a wave of grief coming over him, Sethe explains him, in an unastonished tone as if it were the simplest event on the earth, that the presence is the sad specter of her dead baby, whose throat was cut before it was two years old. Morrison employs the magical realist device of a ghost child, who is later transformed into a human form, to return the memories of intensely disturbed Sethe for whom rememory provides the key to unlock and transform a past that has been suppressed by her logical memory. The expression of the past in the form of Beloved causes the characters to recuperate their memories and to tell their stories. The presence of Beloved as a ghost is oppositional in the novel because "it bothers the scientific and materialist assumptions of western modernity that reality is knowable, predictable and controllable" (Zamora, 1995, p. 498). By bringing this ghost, Morrison deals with the damned heritage of slavery and, by placing Beloved's spirit to the body of a woman who died on one of the slave ships in the 'Middle Passage', she clearly relates her to all the men and women who were enslaved, and the Sixty Million and more Africans who were killed during the passage from liberty to slavery. A close reading of Beloved's monologue reveals that she thinks in images drawn from the unspeakable, unspoken horrors of being captured in Africa and being confined to the hold of a ship on the Middle Passage. In her broken memory, Beloved recalls that she is the only one left in the ship after everybody is taken away, and then she is raped. She considers herself breaking into pieces and plunges into the water to meet the woman she is separated from (Probably her mother). In her novel, Morrison has brought this ancestor into consideration so that she can speak to the living about the cruel and inhuman treatment black people received at the hand of the whites.

Beloved is nothing but a memory comes to life that has easily been forgotten, and she, as a magical character, is a way for the characters to reunite with the past and to reassert identity. What is so poignant about Beloved is the numerous silenced subjects and events, Morrison wants to represent through her, whose claims against history, the past, and the living can never be turned good. Sethe tries her best not to remember her gruesome past, but her brain deceives her; she is overwhelmed by her memories and does not even need any catalytic event. Although she keeps remembering the beauty of Sweet Home, whose landscapes are so vivid and strong that she can hear the wind soughing in the beautiful sycamores, she indeed blocks the memories that are traumatic, and refuses to reproduce the horrors she has witnessed during slavery, and according to Matus (1998), "it is not repression of memory that presents the problem here, but Sethe's consciousness of the amorality of events at sweet home" (p. 106). Far from being obsessed with particular awful scenes, or dysfunctional in not being able to remember the past, Sethe lives in a continuous state of being engulfed by colorful memories. These examples show Sethe in constant trouble with her memory, rebuking either its room for pain or preference for pleasure. Although Morrison skillfully allows Sethe to remember too much of her past, at the same time, she uses fragmented and discontinuous narrative to repress memory. By allowing Sethe's overpowering remembrance of the past, which attempts to make the past vivid to the reader but reveals that she lives in a world deprived of sensation, Morrison indicates the trauma in different way than through the failure of memory. Until the arrival of Paul D, Sethe has been living enslaved by her memories and she shows no interest in the present or future. "But her brain was not interested in the future. Loaded with the past and hungry for more, it left her no room to imagine, let alone plan for, the next day" (Morrison, 1988, p. 70). 
Sethe and other ex-slaves are haunted by Beloved because of their failure to express the history of slavery. Her arrival gradually releases a chain of restrained memories in Sethe, who starts remembering her mother and the earrings Mrs. Garner gave her, and also shares these untold stories with Beloved and Denver and, to some extent, in Paul D who begins to remember Alfred, Georgia and a rooster named Mister. The arrival of Beloved produces a transformation in Sethe which allows her to speak the most unspeakable things in her life, and thus enables her to reveal the past story, especially, the cruelty of slavery which has been excluded in the white slave-owners' history and which is unknown to general people. Shannin Schroeder (2004) believes that Beloved, who is used as a magical realist device, confronts this account of slavery by revisiting the past and by "revising slavery's effects on individuals and by proposing an alternative to that past" (p. 106). Beloved also arouse memories in Denver as she remembers going to school for one year at Lady Jones' house until she was asked about her mother.

\section{Individual and Communal Identity}

Like other ex-slaves, Sethe wants to remember the past but fails to do so because of the brutality it possess; she wants to forget but fails either as she always lives in the past. The magical realist instrument Beloved helps Sethe assert her identity, and, by healing the drift between her and the black community, also enables them to form their communal identity. Sethe and other black people of the community are dissociated from the past so that they can forget the brutal treatment they received in the past, and this desire ultimately causes a fragmentation of self and a loss of true identity. Morrison thematizes the unwillingness of the community to confront the past directly in two significant ways: first, by having the events of eighteen years earlier which resulted in a remorseless confrontation between Sethe and her neighbors, the novel emphasizes that no one wants to think about the day when community did not warn Sethe of Schoolteacher's appearance at 124 Bluestone Road; secondly, in the final pages of the novel, the narrative voice mirrors how quickly Beloved is forgotten: "Disremembered and unaccounted for, she cannot be lost because no one is looking for her" (Morrison, 1988, p. 274). Morrison introduces Beloved as a magical realist instrument who, by reminding Sethe and other ex-slaves of their past, ultimately helps them reassert their identity and fill the void in their selves.

The theoreticians and practitioners of magical realism also emphasize the important role of community. Faris and Zamora (1995) write, magical realist texts "may encode the strengths of communities even more than the struggle of individuals. Societies, rather than personalities, tend to rise and fall in magical realist fiction" (p. 10). In Beloved, Morrison described the communal unity, during slavery and its aftermath where black people, through their experiences, responded to the modern world not only as individuals but also as a group, a community. "The black women, gathered in front of 124 , transform themselves by the sound of their singing into a powerful black church that liberates Denver and Sethe from the oppressive spiritual presence of Beloved" (Lobodziec, 2012, p. 116). Lady Jones devotes her entire life to educate the unpicked and the unprivileged, and, in order to help Sethe and Denver, she invites other black people of the community who share their food with the helpless mother and daughter. Again, as a chain-gang prisoner, Paul D needs support of the other forty-five men for his survival. All these events emphasize the importance of community in the novel.

Despite critical attempts to fix Beloved's identity as Sethe's daughter or as an imposter, it seems clear enough that the ghost is a layering of unstable and suggestive identities, whose fundamental unknowability is the very point. "Beloved may be effectively linked to the Freudian concept of the 'return of the repressed': literally, she returns as the murdered daughter who has been forgotten by the community, but she also represents other memories that Paul D and Sethe have successfully repressed for years" (Peterson, 2008, p. 49). The return of the repressed can result in eye-opening, disturbing moments of recognition, and indeed this happens in Beloved as the initial part draws to a close and everything seems to be falling apart. Morrison wants her characters to remember their past and the inhuman treatment received by the slaves, and Beloved's presence and influence make a necessary but painful reckoning with the past possible, bringing to consciousness the tragedies and brutalities of slavery. Beloved does not merely symbolize the spirit of Sethe's daughter but also stands for the subdued collective memory of violated people, and literally and symbolically becomes the internal language of the pain externalized. Karla Halloway reads Beloved's connection to enormous suffering not only as overwhelming loss but as the prospect of healing:

If Beloved is not only Sethe's dead daughter returned, but the return of all the faces, all the drowned, but remembered, faces of mothers and their children who have lost their being because of the force of ....Euro American slave-history, then she has become a cultural mooring place, a moment for reclamation and for renaming. (cited in Peterson, 2008, p. 54)

Morrison creates a bridge between communal and individual memories through the character of Beloved. Sethe tells Denver, "Some things go. Pass on. Some things just stay. I used to think it was my rememory [....] even if I 
die, the picture of what I did, or knew, or saw is still out there. Right in the place where it happened" (Morrison, 1988, p. 35-36). When Denver asks whether other people can see it, Sethe replies: "Oh yes. Oh, yes, yes, yes. Someday you be walking down the road and you hear something or see something going on. So clear. And you think it's you thinking it up. A thought picture. But no. It's when you bump into a rememory that belongs to somebody else" (p. 36). By acknowledging this collective history and pain, Sethe paves the way for Beloved's obtaining the physical shape in the novel. Beloved's return symbolizes not only Sethe's individual past but also the communal past of the ex-slaves; it represents Ella's child, the fugitive captive from Deer Creek, and, most importantly, 'Middle Passage'. The characters create a bond among themselves through the memories of the traumatic experiences of the past; after getting an opportunity to share history, they recollect and excel terror and thus heal the personal and the collective trauma.

Beloved's stories and action suggest that she symbolizes all the children taken away from their families, and subjugated in the white culture. She can rightly be considered not only as an expression of Sethe's guilt but also as an association between the individual and the community, the personal and the communal history. "The two histories are connected in Beloved's flesh form as she makes it possible to deal with these memories in a way that healing of some wounds becomes possible" (Razmi \& Jamali, 2012, p. 118). Later, Beloved is found to be evil, and is eventually exorcised by the women of the community. The pain Sethe is experiencing is noticed by the community through the appearance of Beloved; they feel the necessity of standing beside her, helping her get rid of the sufferings, and asserting her own identity. According to Foreman, "Beloved's most basic premise lies in the magical; it is the community's shared belief in magic that enables them to save Sethe from Beloved's negative effect" (cited in Razmi \& Jamali, 2012, p. 118). Beloved's presence allows the community to not only understand Sethe's sufferings but also remember their disremembered selves, and seeing Beloved, the singing women confront not only Sethe's past but also their own past. "When they caught up with each other, all thirty, and arrived at 124, the first thing they saw was not Denver sitting on the steps, but themselves. Younger, stronger, even as little girls lying in the grass asleep. Catfish was popping grease in the pan and they saw themselves scoop German potato salad onto the plate" (Morrison, 1988, p. 258). In consequence, their images of a younger self, which was caused by the presence of Beloved, let them recognize a spirituality shattered by the experience of slavery. In this way, they are able to call forth their disremembered selves created in slavery.

Whereas in Part 1 and 2 of the novel, Beloved symbolizes the past of slavery and the mother-daughter relationship, in Part 3 she becomes greedy, unquenchable, and revengeful. It is quite evident that in spite of all of Sethe's explanations, love, and attempt to justify her infanticide, Beloved can neither forget nor forgive, and can only assert her own feelings of desertion and pain. There is something so dangerous about her desire to take revenge on Sethe that it seems unearthly, and it is Denver who understands quickly that she needs help for her mother when Sethe spits up something she did not eat, which signifies the way Beloved has started to possess her body and soul; Beloved is transformed into a witch, a devil, or a succubus. When Denver rushes to the people of community for help, they do not want to repeat the same mistake they committed eighteen years ago when they, out of jealousy, failed to inform Sethe of the arrival of Schoolteacher and his team which resulted in a tragic infanticide and Sethe's alienation from the rest of the community. Besides these, Beloved seems pregnant and "the community of women at the end cannot allow Beloved to deliver a child that would remind them of their forced reproduction under slavery, and they are motivated to find a way to exorcise her from Sethe and their own lives" (Peterson, 2008, p. 57). Thus, the necessity of getting rid of Beloved and the desire to reorganize the past, once again gives the community a chance to amend their mistake, and they decide to exorcise her for the final time. Through Morrison's magical realist instrument Beloved, Sethe and other people of the community become reunited; Sethe is able to reappear from the space of rememory and reassert her identity through the help of other community members.

Beloved's disappearance among the singing and dancing women remains as mysterious as her appearance. The community of black women has decided to admit seethe in their team after a long standoff and alienation of eighteen years, and Beloved, who is a devil child symbolizing greed and vengeance, is unmatched for and unwanted in the community. Morrison represents the return of the repressed past of Sethe, Paul D, Baby Suggs, and other people of the black community through the character of Beloved, and forces us to face the historical past as a living and spiteful presence. Through the demonic characteristics of Beloved's character, Morrison draws our attention to historical atrocities but she must be exorcised in order for a history of trauma to relinquish its hold and allow African Americans to go on living.

\section{Conclusion}

Toni Morrison was not really concerned about a nation, subcontinent or continent but focused mainly on a marginalized community and their struggle against white supremacy. Her Beloved is indeed an unrepresentable 
story told from the perspectives of women, and, by using magical realism, she creates a history for these women and for people of the community to convey the real which has so long been ignored and excluded. In this novel, she employs magical realism as a resistance against the white American culture and history; she uses the technique to rewrite the slave history from their own perspectives, and to form an identity lost through slavery. By introducing a magical character with a narrative voice, Beloved alters the established notion of reality in accordance with Eurocentric definitions. This magical character Beloved reminds Sethe of her brutal past which she never wants to remember, enables her to create her history which has largely been ignored in the white slave-owners' version of history, and helps her form an identity. The character Beloved herself is a magical realist device used by Morrison to make the absence of past slavery present, and to deal with the bloody legacy of slavery. By linking Beloved to all male and female died in the 'Middle Passage', Morrison actually represents her as both the individual and the communal past, and the representative of the marginalized and the disempowered. Through Sethe and the community's remembrance and knowledge of the past and a sense of identity, Morrison provides an alternative history from the perspective of the slaves.

\section{References}

Bowers, M. A. (2004). Magic(al) realism. London and New York: Routledge.

Chanady, A. (1995). The territorialization of the imaginary in Latin America: Self-affirmation and resistance to metropolitan paradigms. In L. P. Zamora \& W. B. Faris (Eds.), Magical realism: Theory, history, community (pp. 125-144). Durham \& London: Duke University Press.

Faris, W. B. (2004). Ordinary enchantments: Magical realism and the remystification of narrative. Nashville: Vanderbilt University Press.

Lobodziec, A. (2012). Toni Morrison's discredited magic-magical realism in Beloved revisited. Brno Studies in English, 38(1), 103-121. http://dx.doi.org/10.5817/BSE2012-1-7

Matus, J. (1998). Toni Morrison. Manchester \& New York: Manchester University Press.

Morrison, T. (1988). Beloved. (First Picador ed.). London: Picador.

Peterson, N. J. (2008). Beloved: Character studies. New York: Continuum.

Razmi, M., \& Jamali, L. (2012). Magic(al) realism as postcolonial device in Toni Morrison's Beloved. International Journal of Humanities and Social Science, 2(5), 112-119.

Rushdy, A. H. A. (1999). Daughter signifyin(g) history: The example of Toni Morrison's Beloved. In W. L. Andrews \& N. Y. Mckay (Eds.), Toni Morrison's Beloved: A casebook. (pp. 37-66). Oxford: Oxford University Press.

Samuels, W. D., \& Hudson-Weems, C. (1990). Toni Morrison. Boston: Twayne Publishers.

Schroeder, S. (2004). Rediscovering magical realism in the Americas. Westport, Connecticut: Praeger Publishers.

Taylor-Guthrie, D. (Ed.). (1994). Conversations with Toni Morrison. Jackson: Mississippi University Press.

Zamora, L. P. (1995). Magical romance/magical realism: Ghosts in U. S. and Latin American fiction. In L. P. Zamora \& W. B. Faris (Eds.), Magical realism: Theory, history, community (pp. 497-550). Durham \& London: Duke University Press.

Zamora, L. P., \& Faris, W. B. (1995). Introduction: Daiquiri birds and flaubertian parrot(ie)s. In L. P. Zamora \& W. B. Faris (Eds.), Magical realism: Theory, history, community (pp. 1-11). Durham \& London: Duke University Press.

\section{Copyrights}

Copyright for this article is retained by the author(s), with first publication rights granted to the journal.

This is an open-access article distributed under the terms and conditions of the Creative Commons Attribution license (http://creativecommons.org/licenses/by/3.0/). 